\title{
THE END OF THE HONEYMOON: PENAL DISCOURSE AND THE HUMAN RIGHTS OF PRISONERS IN THE AFTERMATH OF SOUTH AFRICA'S SECOND DEMOCRATIC ELECTION - PART TWO
}

\author{
Stephen Allister Peté \\ BA LLB LLM M Phil PhD \\ Associate Professor of Law, School of Law \\ University of KwaZulu-Natal
}

\section{SUMMARY}

The years immediately following South Africa's second democratic election, held in June 1999, were significant in that they marked the end of the "honeymoon" period which followed the country's transition from apartheid to democracy in 1994. This article focuses on the public discourse surrounding imprisonment in South Africa during this important "post-honeymoon" period. The article traces the continued systematic violation of the basic human rights of many of those confined in South African prisons throughout the period. Part One of the article dealt with the many public debates surrounding chronic prison overcrowding and its effects, whereas Part Two deals with a host of evils which beset the South African penal system at this time, including very poor conditions of detention, high levels of gang activity, the spread of HIV/AIDS, the escape of dangerous criminals from different prisons in the country, and instances of corruption and other criminal activity amongst prisoners and staff.

\section{INTRODUCTION}

The central purpose of this article is to examine penal discourse and the human rights of prisoners in the aftermath of South Africa's second democratic election, which was held on 2 June 1999. As pointed out in the introduction to Part One of this article, this election was important, in that it served to consolidate South Africa's hard won constitutional democracy. It was also important in that it marked the end of the "honeymoon period" which had followed the country's miraculous transition from the period of apartheid, to a period characterized by the principles of constitutional democracy and respect for human rights. The end of the "honeymoon period" was marked by ever-increasing levels of public anxiety over the unacceptably high levels of crime in the country. As pointed out in Part One of this article, this anxiety affected the colour and tone of public debate in 
many other areas of South African life, including the punishment of offenders. It was during this post-honeymoon period that South Africans came to realize that the end of apartheid did not mean an end to the abuse of prisoners' basic human rights in poorly maintained and chronically overcrowded prisons, with significant levels of gang activity, and high rates of HIV infection.

Part One of this article examined the public penal discourse surrounding prison overcrowding. The main conclusion reached was that chronic overcrowding within South Africa's prisons remained a major problem during the period following the country's second democratic election. Furthermore, it was shown that all concerned - both those involved in prison administration as well as the public at large - were well aware of the manner in which chronic overcrowding was effectively depriving thousands of South African prisoners of their basic human rights. It was even speculated that overcrowded prisons - with all the negative consequences that this entails may be the inevitable result of efforts to keep order in a chronically unequal society, in which millions live in appalling conditions below the poverty line.

Part Two of this article will continue building upon the overarching theme of human suffering within South Africa's prisons during the post-apartheid period. In particular, it will examine the public discourse surrounding a range of different "evils" which accompanied the chronic overcrowding of the country's prisons immediately following the second democratic election. These evils include poor conditions of detention (particularly distressing in the case of vulnerable classes of prisoners such as children); high levels of gang activity; the spread of HIV/AIDS; the escape of dangerous criminals from different prisons in the country; and instances of corruption and other criminal activity amongst prisoners and staff.

As mentioned in the introduction to Part One of this article, the research which went into both Parts One and Two of the article, makes use of data drawn from a large number of newspaper reports which appeared in a wide variety of South African newspapers during the period in question. It also makes use of data drawn from official reports and speeches by public officials. The richness of this data produces a vivid picture of a particular time in South Africa's penal history. The conclusions which may be drawn, however, are not relevant only to a particular historical period, but may be useful to our current understanding of the South African penal system.

\section{DISCOURSE SURROUNDING THE SPREAD OF HIV/AIDS IN SOUTH AFRICAN PRISONS}

One of the major developments which affected the human rights of prisoners in South Africa during the period under review was the uncontrolled spread

\footnotetext{
There is considerable truth in the following well-known phrase which appeared in the 13 June 1948 edition of the Washington Post: "News is a first rough-draft of history" (see website: http://www.slate.com/articles/news_and_politics/press_box/2010/08/who_said_it_ first.html (accessed 2015-03-07).
} 
of HIV within the prisons, and the increasing numbers of prisoners who began to succumb to AIDS-related illnesses. The issue began to generate political heat towards the end of 1999, when the Minister of Correctional Services, Ben Skosana, addressed Parliament on the issue of whether or not HIV-positive prisoners should be separated from other prisoners. The Minister stated that HIV-positive prisoners were not held separately from other prisoners, since this would impinge on their right to confidentiality. Furthermore, it was impossible to separate prisoners in this way for the simple reason that South Africa's prisons were too overcrowded. Prisoners with full-blown AIDS and who were bleeding, incontinent, unconscious or displaying persistent AIDS-related infections like tuberculosis, were, however, medically isolated. He stated that 40 terminally ill prisoners had been released on medical grounds since January 1999. This allowed these prisoners, who had been rendered helpless by disease, to die at home or within a specific institution. ${ }^{2}$ Opposition parties were quick to take the Government to task for its lack of a comprehensive policy to halt the epidemic. The New National Party called on the Government to ensure that all prisoners were tested for HIV/AIDS upon entering and leaving prison. This would indicate how many prisoners were infected with the AIDS virus while being held in prison. A spokesperson for the party, Johann Durand, stated that he was outraged that the Department of Correctional Services did not consider the spread of AIDS in prisons to be a threat:

"The NNP demands that the Government open the debate on possible measures which can be taken to prevent the spread of Aids in prisons. Much work needs to be done to find effective means to reduce transmission of HIV by sex and drugs in prison. The failure to provide basic measures, such as information, education and the means of prevention available on the outside, violates the rights of prisoners to health, security of person and equality before the law".

The Department of Correctional Services responded to the call by the New National Party to have all prisoners tested for AIDS, by stating that, in terms of guidelines promulgated by the World Health Organization, it would be unethical to introduce compulsory testing. ${ }^{4}$

While the political wrangling was going on, increasing numbers of prisoners were falling ill and dying. In November 1999, it was reported that the 68 prisoners with full-blown AIDS were being treated symptomatically for AIDS-related illnesses such as diarrhea, tuberculosis and sexually transmitted diseases, but that no prisoners with AIDS were being treated with antiretroviral AIDS drugs like AZT. ${ }^{5}$ During the same month, it was reported that the Department of Correctional Services had embarked on a policy of releasing terminally-ill prisoners who were in the final stage of irreversible diseases, including those with AIDS - in order to reduce the cost of treating such prisoners. Human-rights campaigners were reported to be

12 November 1999 The Daily News 3.

22 November 1999 The Citizen 4.

23 November 1999 Beeld 11.

24 November 1999 The Star 11. 
concerned that the Government was shirking its responsibility to care for such terminally-ill patients. ${ }^{6}$

Halfway through the following year, the epidemic appeared to be getting worse. In July 2000 the Pretoria News reported that an alarming rise in the number of sick and dying persons in prisons was "draining the already beleaguered coffers of the Department of Correctional Services". A large number of the 521 prisoners who died in Gauteng during the first half of 2000 - were believed to have died as a result of AIDS-related infections. This figure was expected to double by the end of 2000 , and would be considerably higher than the total of 534 prisoners who died during 1998. In KwaZulu-Natal, there were 144 prison deaths during 1998; 194 during 1999 and 127 during the first seven months of 2000 . The Minister of Correctional Services admitted that sick prisoners were already placing a huge financial strain on the Department. ${ }^{7}$

During the same month that the alarming information referred to above was revealed to the public, it was reported in the Mail and Guardian that a man, who had contracted HIV while incarcerated in Pollsmoor prison six years previously, was suing the Minister of Correctional Services in the Cape High Court. The action had been instituted three years previously in 1997. It would act as a test case to determine whether the Department of Correctional Services was legally liable for failing to provide adequate protection to inmates, as well as failing to act against the increasing incidence of rape among prisoners. The newspaper reported that there were 2700 known HIV-positive prisoners among South Africa's prison population of 172000 . The report pointed out, however, that the rate of HIV-infection was probably much higher than this, and commented that:

"Prisoners say HIV status can be used as a means to assert power and obtain favours through the threat of rape, while some prison gangs practise sodomy as part of their culture. Infection is also spread through sharing needles used for tattooing gang members ... Prison doctors see only a small proportion of the rape survivors because of feelings of shame or threats of further violence".

Public concern on the issue did not diminish in the months which followed. During September 2000 it was again pointed out in the press that there had been an alarming increase in the number of prisoners dying from tuberculosis and other AIDS-related diseases. It was reported that, since December 1996, there had been a 30\% increase in the number of tuberculosis cases in South African prisons. The number of prisoners who had died in South African prisons (excluding deaths in police cells) had increased from 402 in 1997, to 534 in 1998, to 737 in 1999. A total of 663 had died from January to July 2000 . The situation was made worse by chronic overcrowding, and due to uncompetitive salary structures, the Department of Correctional Services was unable to employ suitably qualified

\footnotetext{
11 November 1999 Sowetan 1.

26 July 2000 Pretoria News 2.

28 July-3 August 2000 Mail and Guardian 15.
} 
medical personnel. ${ }^{9}$ In the face of this mounting crisis, the Minister for Correctional Services announced, at a parliamentary briefing, that offenders could soon be tested for AIDS upon their arrival in prison. Testing would be anonymous and aimed at determining the extent of the epidemic among inmates. The Minister revealed that the number of prisoners known to be HIV positive had increased by $300 \%$ from 1997 to 2000, and announced that a new AIDS policy for prisons was being formulated..$^{10}$ The South African Prisoners Organization for Human Rights also responded to the mounting crisis. The president of the organization, Mr Golden Miles Bhudu, called on the Department of Correctional Services to release those prisoners who were terminally ill with AIDS, into the care of their families. He stated that: "If they test positive, they must be released in the early stages, so that when they have full-blown AIDS and are terminally ill, they are the responsibility of their families". ${ }^{11}$

In October 2000, the role of gang behaviour in the spread of HIV/AIDS within South African prisons received further publicity. Three researchers from Vista University - Michelle Minnie, Annette Prins and Eugene van Niekerk - presented a research paper on the topic at a conference in Port Elizabeth, which was reported on in the press. The researchers claimed that gang behaviour in South African prisons, which resulted in the psychological, social and sexual victimization of certain inmates, was playing a significant role in the disastrous spread of HIV/AIDS within the prisons. The Eastern Province Herald reported on Michelle Minnie's submissions to the conference, inter alia, as follows:

"Mrs Minnie said evidence suggested that institutionally induced homosexual acts were rife in prisons and certainly not new to the prison context. For example, one of the chief aims of the powerful "28 Gang" was to actively recruit "wyfies" - young men with feminine traits - and to promote sodomy among its members".

In the same month, Gideon Morris, the Secretary of the Office of the Inspecting Judge, commented on the disturbing rise in the number of South African prisoners dying of AIDS-related illnesses. He pointed out that, whereas 186 prisoners had died as a result of AIDS-related illnesses during 1995, more than 1000 prisoners had already died of such illnesses during 2000. He stated that - according to post-mortem results - AIDS was the most probable cause in $90 \%$ of prison deaths. He also expressed the following deeply shocking opinion:

"It is hard to say precisely, but it is estimated that between $70 \%$ and $80 \%$ of all arrested suspects are being sodomised by fellow prisoners before they are even officially charged. Many of the suspects are raped within the first 48 hours of being detained".

10 September 2000 City Press 5.

1020 September 2000 Die Burger 7; and 20 September 2000 Cape Argus 5. The number of HIV-positive prisoners had increased from 1094 in July 1997 to 3209 in July 2000.

1116 October 2000Cape Argus 4.

126 October 2000 Eastern Province Herald 7.

1317 October 2000 Pretoria News 5. 
According to Morris, many awaiting-trial prisoners received a "death penalty" through AIDS before they had been found guilty by a court of law. He pointed out that $40 \%$ of awaiting-trial prisoners were eventually found not guilty by the court. ${ }^{14}$ According to Morris, massive overcrowding meant that prisoners could not be properly segregated, which resulted in gangsters having access to awaiting-trial prisoners. He submitted that the dramatic increase in the number of prisoners dying of AIDS-related illness was the result of an increase in the number of HIV-positive people entering prison, the high incidence of rape in prison - together with overcrowding. ${ }^{15}$ The Pretoria News commented in an editorial as follows:

"The news that the majority of awaiting trial prisoners are being robbed and sodomised by fellow inmates effectively means that they are being sentenced to death by their Aids-infected rapists. Even more unpalatable should be the fact that about $40 \%$ of these unfortunates will eventually be found not guilty when brought to trial ... Where is the fairness in this? Surely an awaiting trial prisoner deserves respect and protection from the brutality that seems to have become the norm within our correctional institutions? Surely even sentenced prisoners do not deserve such treatment? It is estimated that 45000 inmates will die of Aids in our prisons by 2010 - which gives an indication of just how bad the situation is".

During November 2000, the Minister of Correctional Services announced that a draft policy to deal with AIDS in prisons had been drawn up by the Department of Correctional Services, and was being circulated for comment. ${ }^{17}$

By January of the following year, it was reported that South African prisoners were being screened for HIV/AIDS on entering the prison system, and were provided with pre-test and post-test counselling. A spokesperson for the Department of Correctional Services stated that there were 3200 prisoners who were known to have HIV/AIDS. Mention was made of a report compiled by the United Nations Joint Programme on AIDS, which found the incidence of homosexual sex in Southern African prisons to be high. The report found that in Malawi and Zambia, at least one man in eight engaged in homosexual sex while in prison. ${ }^{18}$

In April 2001, the treatment of prisoners with AIDS was put in the spotlight once again, when City Press reported on the death of an awaiting-trial prisoner, Vusi Nxumalo. Nxumalo, who had full-blown AIDS, died while shackled to a hospital bed and in leg irons. A war of words erupted between the Department of Justice and the Department of Correctional Services, with each blaming the other for failing to ensure that Nxumalo was allowed to die in dignity. Nxumalo's father stated as follows:

"I feel very sad to lose my only son, in whom I had put all my hope. He died a cruel death in the hands of the police and prison warders ... I fail to

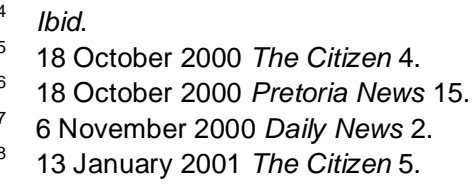


understand why the prison warders decided to chain someone, who was already weak and could hardly lift his head. When he appeared in court he was already in the wheelchair, but still they did not care ...

It was at this time that the Inspecting Judge of Prisons, Judge Johannes Fagan, delivered his annual report to Parliament. He told Parliament that natural deaths in South Africa's prisons had risen by 584\% during the previous five years, and that this rise was due mainly to the impact of HIV/AIDS. ${ }^{20}$ The policy of the Department of Correctional Services was not to subject prisoners to mandatory testing, which meant that the real incidence of HIV/AIDS among prisoners was unknown. A spokesman for Correctional Services admitted, however, that the increase in "natural deaths" in prisons was putting the department's medical budget under considerable pressure.

During August 2001, it was reported that a series of voluntary tests had been conducted on prisoners between January and April 2001 to determine how many were infected with HIV. The survey found that 4105 prisoners were HIV positive, but it was feared that the actual number of HIV-positive prisoners in South African prisons could be much higher. A total of 51 prisoners died of AIDS-related illnesses during the same period. This indicated that an average of 12 prisoners could be expected to die of AIDSrelated illnesses each month. The Department of Correctional Services applied for an additional budget of R600 000 to conduct an HIV-prevalence survey with the Department of Health. Other measures being taken by the Department of Correctional Services to combat the AIDS epidemic in prisons - included HIV-awareness campaigns, peer support groups, the distribution of pamphlets, the showing of audio-visual educational material, and various other initiatives by non-governmental organizations. It was reported that, during the year 2000, the non-governmental organization, Hope World Wide, undertook research into the nature and extent of the AIDS epidemic in South African prisons. This research involved interviews with 300 prisoners, and resulted in the following disturbing findings: $48 \%$ said that they had had two or more sexual partners before they were arrested; $46 \%$ said that they had never used a condom; $31 \%$ were unsure about the risks of disease; $81 \%$ did not know how to get a condom in prison; $52 \%$ were unaware of their HIV status; and $60 \%$ had little knowledge about AIDS. According to the report, the release of prisoners for medical reasons had been restricted to sentenced prisoners, and the organization called on the Department to extend its policy to include awaiting-trial prisoners. The organization felt that such prisoners should be allowed to die in dignity with their loved ones. ${ }^{2}$

In September 2001, the Minister of Correctional Services, Ben Skosana, announced in Parliament that the number of AIDS-related deaths in South African prisons had quadrupled in the first six months of 2001, compared to the first six months of 2000 . Whereas 257 prisoners had died of AIDS-

\footnotetext{
1 April 2001 City Press 1

4 April 2001 Business Day 3.

3 August 2001 Sowetan 13.
} 
related illnesses during the period January to July 2000, 1101 prisoners had died during the period January to July 2001. The total number of prisoners known to be HIV-positive had increased from 3209 to 4368 between 2000 and 2001. The Minister stated that the Department of Correctional Services would not request the Government to allow it to implement a programme of compulsory AIDS testing in prisons, since such a programme would be unconstitutional. According to the Minister, the Department of Correctional Services had set up a dedicated section to coordinate programmes to combat AIDS at the provincial and national level. ${ }^{22}$ During the same month, Judge Johannes Fagan, the head of the Judicial Inspectorate of Prisons, stated that the Correctional Services Act would be amended to allow terminally-ill awaiting-trial prisoners to be released, in order that they could die in a dignified manner. Legislation at the time allowed only for the early release of sentenced prisoners who were terminally ill. ${ }^{23}$ The public was clearly becoming increasingly concerned about the issue, and in its editorial of 29 September 2001, the newspaper Beeld called on the Government to study the increase in the number of AIDS-related deaths in prisons, as a matter of urgency. The newspaper pointed out that prisons comprised a vital part of the democratic order and that it was unacceptable for prisons to become nests for the propagation of AIDS. It characterized the situation as critical and called for drastic steps to be taken. ${ }^{24}$

Researchers also became involved in the public debate concerning the uncontrolled spread of HIV in South African prisons. Sasha Gear and Kindiza Ngubeni of the Centre for the Study of Violence and Reconciliation, conducted a study on sex and rape in South African prisons during the year 2001. On the question of how many prisoners were raped, Gear commented that:

"It is difficult to say how many prisoners are raped or coerced into unwanted sex. What can be said with confidence is that some are more vulnerable to forced sex than others. Physical features certainly play a role ... But those most at risk are awaiting-trial prisoners. Gang leaders often come to the observatory when people arrive, and they point out whom they want."

Gear then went on to describe the relationship between prisoners and their "wives":

"A 'wife' is considered to be nothing. He cannot talk to others without permission; he can be rented out to other men; he rarely leaves his cell. The

2219 September 2001 Beeld 7; 19 September 2001 Natal Witness 1; 20 September 2001 Die Burger 7. Note that the total number of known HIV/AIDS cases in South African prisons provided by the Minister of Correctional Services in September 2001, differ slightly from the following figures, which appear under the heading "Health Care" in part 3.1 of the Department of Correctional Services Annual Report for the period 1 April 2001 to 31 March 2002, and reflect the total number of known HIV/AIDS cases as at 31 December, of each of the following years: $1998=1865$ cases; $1999=2536$ cases; $2000=3397$ cases; $2001=4$ 720 cases.

2326 September 2001 Beeld 3.

2429 September 2001 Beeld 18.

2522 October 2001 Business Day 9. 
'male partner' goes out into the world to do business. His wife is obliged to give him sex when he returns.

Further light was shed on this issue during February 2002, when the South African Prisoners Organization for Human Rights told the Sowetan that a high incidence of sodomy and gang-rape contributed to the increase in HIV-AIDS infections in prisons. According to the organization, the chances of someone being sent to prison HIV-negative and coming out HIV-positive were extremely high. It was alleged by the South African Prisoners Organization for Human Rights that some warders turned a blind eye to rapes in prison, or even accepted bribes to allow gang members to access new inmates for the purposes of rape. According to the deputy director of medical-support services in prisons, Maria Mabena, HIV-positive prisoners died faster than persons outside prison, who were diagnosed at approximately the same time:

"There are various reasons for this, including overcrowding, bad diet, the immune system being compromised, limited movement and stress. Most prisoners are uncooperative. They sometimes refuse to do things such as exercise that would improve their health status.

The following month, the Institute for Security Studies issued a warning that, if sodomy and sexual violence in South African prisons were not curbed, AIDS would continue to spread, resulting in massive death rates over the next five to ten years. ${ }^{28}$ In its editorial of 19 March 2002, The Star commented on the problem of male rape in prisons as follows:

"This problem has a huge ripple effect. The incidence of HIV/Aids, already believed to be rampant in prison, is likely to rise with forced anal intercourse. Brutalized men often go into society changed men - but not for the better. And, say the experts, prisons become the training ground for future violent acts of crime perpetrated by these ex-prisoners. Our jails have become, it seems, places where bad people are sent to become worse people ... Central to the problem are factors such as cells meant for six men housing 16 inmates, that the prison authorities allow gangs free reign, and that warders are not infrequently corrupted by such gangs.

It is clear, therefore, that the spread of HIV among the South African prison population, as well as increasing numbers of deaths due to AIDSrelated illnesses, remained serious problems throughout the period under examination in this article. The public discourse surrounding this issue reflects the immense suffering to which thousands of South African prisoners were subjected at this time. The appalling conditions in many prisons allowed the HIV epidemic to spread like wildfire, with the main "culprits" being chronic overcrowding and rampant gang activity. The most basic human rights of many prisoners were seriously compromised, as the

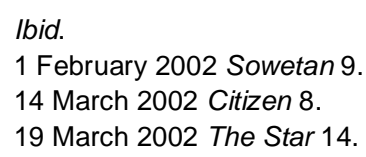


nightmare of the epidemic unfolded before the eyes of the South African public and prison officials.

\section{THE CONTINUED VULNERABILITY OF JUVENILE OFFENDERS IN ADULT PRISONS}

The chronically overcrowded state of South African prisons during the period under review impacted particularly harshly upon prisoners who were vulnerable in some way. Juvenile prisoners were one such group - many of whom were detained in adult prisons throughout South Africa. This was despite efforts on the part of the Government, in the years preceding this, to build separate accommodation for juvenile prisoners. ${ }^{30}$ During July 1999 it was reported that about 275 juvenile prisoners were detained awaiting trial in various prisons in Gauteng. ${ }^{31}$ Two months later, the director of research and programme development at the National Institute for Crime Prevention and the Rehabilitation of Offenders, Lukas Muntingh, pointed out that: "The greatest tragedy is that there are more children awaiting trial in South Africa's prisons today than there were in 1994 when Mandela's Government came to power." ${ }^{32}$

Life for juveniles at this time in South Africa's overcrowded adult prisons was described as "hell". For example, one 15-year-old who had been held as an awaiting-trial prisoner in the severely overcrowded Pollsmoor Prison on two occasions reported he had experienced beatings and gang violence, and had almost been stabbed to death. He described lice-infested beds and unhygienic living conditions. He complained that the last meal of the day was served at midday, and that the monotony of the day was broken only by the occasional workshop. ${ }^{33}$ Almost a year later, in June 2000, the plight of juvenile prisoners in Pollsmoor did not seem to have improved much. At this time, 396 juveniles aged 14 to 17 years were being detained in the severely overcrowded prison. Western Cape Commissioner of Correctional Services, Stephen Korabie, threatened to stop any new admissions to the prison because of the chronic overcrowding, and Pan Africanist Member of Parliament, Patricia de Lille, threatened to apply for a High Court interdict to prevent any more juveniles being detained to Pollsmoor Prison for petty offences. In response to this political and legal pressure, the head of the Western Cape Department of Justice, Hisham Mohamed, stated that closing the prison would not solve the problem of overcrowding. He pointed out that two months previously, nine new courts had been established in the Western Cape to deal with the backlog of court cases - which was a major cause of the overcrowding. In addition, he had held a meeting with chief magistrates

30 For an account of the race to provide separate and sufficient secure accommodation for juvenile offenders in South Africa during the period leading up to the second democratic election, see Peté "The Good, the Bad and the Warehoused": The Politics of Imprisonment During the Run-Up to South Africa's Second Democratic Election 2000 13(1) South African Journal of Criminal Justice 1-56 Section 9.4. 20 July 1999 Sowetan 5

19 September 1999 The Sunday Independent 3.

33 Ibid. 
to examine ways in which juvenile-court rolls could be processed more quickly. Furthermore, the Department of Welfare had agreed to take 60 children to a place-of-safety facility at Faure. Mohamed stated that a task team had been initiated at the Wynberg Court to examine all awaiting-trial prison cases, and pointed out that an additional R2.8 million had been invested to help speed up the processing of cases. ${ }^{34}$ The following month, the Minister of Correctional Services, Ben Skosana, visited juvenile offenders in the chronically overcrowded Pollsmoor Prison, and commented that:

"A prison is not a place for children. I have been touched by the conditions inside the prison. This is a problem too big for one department. It needs cooperation with the departments of Welfare and Education."

The District Surgeon responsible for Pollsmoor Prison, Dr Paul Theron, described the conditions under which juvenile offenders were held in the prison, as a catastrophe. He claimed that the human rights of the children were being violated on a daily basis. There was overcrowding, a lack of basic amenities like clean toilets and washing facilities, and general chaos in the daily existence of warders and prisoners. Approximately 1500 awaitingtrial children, and juveniles younger than 19 were confined with 476 sentenced children - as well as about 400 adults. Children were forced to sleep in shifts, since there was not nearly sufficient bedding. It was feared that more than half the children were infected with HIV. Theron prepared a report on the health of the juveniles imprisoned in Pollsmoor, in which he concluded that one in every three prisoners suffered from a sexually transmitted disease. A third of offenders suffered complications arising from bullet and stab wounds, as well as old amputations. Smoking-related illnesses were common, while many young prisoners used dagga, mandrax and cocaine. Most young prisoners suffered from depression, dizziness and aggression. ${ }^{36}$

The response of the authorities to the plight of juvenile offenders in Pollsmoor Prison, was not sufficient to prevent Patricia de Lille - together with three concerned mothers of children confined in the prison - from launching an urgent application in the Cape High Court against the Ministers of Justice and Correctional Services; the Western Cape MEC for Education; and the Officer Commanding Pollsmoor Prison. ${ }^{37}$ On 18 July 2000, Mrs Justice Jolyn Knoll ordered the removal of about 300 children from Pollsmoor prison to places of safety. The Minister of Correctional Services and the Officer Commanding the prison were ordered to ensure that all children at the prison be examined immediately by a district surgeon. They were further required to ensure that the children be provided with medical and psychological treatment. Finally, they were ordered to enquire into the circumstances of the accommodation and detention of all children at

12 June 2000 Cape Argus 4.

6 July 2000 The Cape Times 3.

12 July 2000 Die Burger 1.

18 July 2000 The Citizen 2. 
Pollsmoor, and to determine whether it was reasonable, practicable and lawful to transfer them to other places of accommodation and detention. ${ }^{38}$ The Sowetan reported that: "De Lille's victory was bitter-sweet when it was revealed that one of the children to be released from Pollsmoor had raped and murdered her sister two years ago".

In response to the legal action outlined above, the Minister of Correctional Services instructed his provincial commissioners to establish task teams to ensure that children confined in prisons across the country be provided with basic health care and transferred to places of safety. It was reported that, out of 28090 juveniles in custody, 4253 children were being held in South African prisons at the time. ${ }^{40}$ The Minister of Correctional Services was clearly unhappy with the state of his department and complained that: "We must not find ourselves being compelled through a High Court order to adhere to minimum acceptable standards of conditions of detention". ${ }^{41}$ It was reported that the Minister had given his commissioners a one-month deadline to put in place plans for the transfer of children into places of safety or reformatories. Provincial commissioners were required to establish healthtask forces to monitor the health conditions of prisoners, and to formulate methods for the treatment and prevention of contagious diseases. The Minister warned that he had been considering taking drastic steps to reduce the number of awaiting-trial prisoners. ${ }^{42}$

Patricia De Lille kept up the political pressure on the Department of Correctional Services by visiting the Johannesburg Central Prison at the end of July 2000. As a result of this visit, it was announced that 72 awaiting-trial juveniles in the prison would be transferred to a place of safety. Eleven children would remain in the prison because of the seriousness of their crimes. De Lille commented that the cells were surprisingly clean, but overcrowded - with 35 children sharing a cell designed for 19 prisoners. The prison kitchen, which was designed to cater for 3000 prisoners, was forced to cater for 6500 people. She stated as follows:

"We cannot keep children under these conditions. It's not a good reflection on us as a nation ... This is actually where we produce criminals. If we save some, we'll send fewer hardened criminals back into society and begin to break part of the cycle of violence and crime."

During September 2000, child activists, Pricilla and Jessica McKay, told an international conference in Durban that the way in which children in South African prisons were being treated was a violation of the United Nations Convention on the Rights of the Child, as well as the South African Constitution. Referring to Durban's Westville prison, they claimed that on any given day, 60 to 90 children shared a space big enough for only 19 people. The children had to share a single toilet, and only two toilet rolls

\footnotetext{
19 July 2000 The Citizen 7.

21 July, 3 Sowetan.

21 July, 3 Sowetan.

24 July 2000 The Star 2.

24 July 2000 The Star 2; 24 June 2000 Natal Witness 2.

4324 July 2000 Sowetan 6.
} 
were issued for the use of all the children each day. Mattresses were so scarce that each thin mattress had to be shared by three children. The activists claimed that during the month of August 2000, there were 500 children in the awaiting-trial section of the Westville prison - which meant that the section was overcrowded by a massive $300 \%$. The children in this prison complained of being cold in winter. They also complained that there were only two social workers and four child-care workers to care for about 500 children. The children were locked up unsupervised from 2 o'clock in the afternoon until 9 o'clock the next morning - resulting in a "high potential for sodomy". The activists concluded that:

"Prisons are not fit places for children. The conditions in the awaiting-trial section constitute a punishment before the child's trial has even begun ... Because of poverty, unemployment, homelessness, school dropouts and HIV/Aids, children will continue to fall foul of the law. It is therefore essential to abide by the Convention on the Rights of the Child and the constitution and to provide adequate alternative care ... They are the future of our country."

Two months after the above statement was made, it was reported that 467 children were being held in Durban's Westville Prison. A spokesperson for the South African Prisoners Organization for Human Rights, alleged that some of these children had been held, awaiting trial, for up to three years without being released or given bail. The director of a group known as "Children's Rights Ministry", the Reverend Livingston Jacob, described the conditions under which the children were kept as "shocking and overcrowded". ${ }^{45}$ He stated further:

"I was deeply shocked to hear some of their complaints. They told me they were treated badly; some of them were beaten up and assaulted by the wardens. A particular boy was sjambokked consistently. I witnessed, firsthand, bruises on his body ... There are no constructive programmes for these children. If the wardens treat children like animals then they are going to retaliate and take revenge on innocent people in civil society".

During the same month, the Minister of Correctional Services, Ben Skosana, told the Pretoria Press Club that - due to overcrowding in the prisons - more than 3000 children were being confined together with adult prisoners. He stated that there were no facilities to detain these children separately. He referred to a recent case in which two brothers aged 12 and 13 years respectively, were sent to prison on a charge of housebreaking and theft. The head of the prison to which they were sent at first refused to admit these children - but was warned that he would be guilty of contempt of court if he continued to refuse to lock the children up. ${ }^{47}$

Amidst the gloom surrounding the treatment of juveniles in South African prisons during the period under review, one ray of light was the progress made by the South African Law Commission towards creating a new

\footnotetext{
445 September 2000 The Star 6.

4523 November 2000 Daily News 1.

46 Ibid.

4729 November 2001 Beeld 22.
} 
procedural system for children who came into conflict with the law. During September 1999, it was reported that the Law Commission's project committee on juvenile justice had circulated a discussion paper for comment, and hoped to evaluate the final draft legislation in early December 1999 - with a view to presenting it to Parliament in mid-2000. ${ }^{48}$ In general, however, it is clear that the human rights of juveniles detained in South African prisons during the period under review were severely compromised.

\section{CONCERN OVER MASS ESCAPES}

Despite a general drop in the number of escapes by prisoners during the period under review, the manner in which those escapes that did take place were effected, was cause for serious concern. ${ }^{49}$ On a number of occasions, large numbers of prisoners managed to escape - either by using violence or with the assistance of corrupt prison officials. During July 1999, for example, a group of gunmen armed with AK47-assault rifles forced a Correctional Services vehicle off the road and freed a group of awaiting-trial prisoners who were being transported from Pollsmoor Prison to court. Thirty of the 48 prisoners who were being transported escaped, but 17 were quickly rearrested. Among those rearrested was Junior Zulu, the suspected member of a group of dangerous criminals who specialized in cash-in-transit robberies. It was believed that this group had planned and executed the military-style operation in order to free Zulu. ${ }^{50}$ Two months after this incident, it was reported that 21 awaiting-trial prisoners had escaped from the Pietermaritzburg New Prison by cutting through iron bars with an angle grinder. ${ }^{51}$ In an editorial, the Natal Witness commented, inter alia, that:

"The escape raises serious questions. How could the angle grinder equipment being used in current prison renovations - have been acquired without the knowledge of prison staff? And how was it that the prisoners were able to use this very noisy cutting tool in the early hours of a Saturday without alerting anyone in authority? Was there connivance? Or was there virtually no supervision at the prison over the weekend? How motivated are prison staff to perform their duties diligently? Is morale high, or has it been sapped by the controversies surrounding upper-staff echelons in the past year, and, perhaps, by the incompetence of some top brass. Something is seriously wrong at the Pietermaritzburg New Prison."

The chairperson of Parliament's Correctional Services Portfolio Committee, Aubrey Mokoena, visited Pietermaritzburg New Prison and described the conditions he found there as abnormal and outrageous. He

$48 \quad 19$ September 1999 The Sunday Independent 3.

49 The number of escapes by prisoners dropped significantly between 1995 and 2000: 1995 (1247); 1996 (1345); 1997 (1050); 1998 (497); 1999 (425); 2000 (236) - See City Press, 11 February 2001, 22. Escapes from prison itself, from work teams, from public hospitals, from courts, and during escorts, totalled 241 during the period 1 April 2000 to 31 March 2001, and 233 during the period 1 April 2001 to 31 March 2002 (see the Department of Correctional Services Annual Report for the period 1 April 2001 to 31 March 2002, Part 3.1 Escapes from Custody).

508 July 1999 The Star 2; 8 July 1999 Cape Argus 1.

5120 September 1999 Natal Witness 3.

5222 September 1999 Natal Witness 8. 
raised concerns about the overcrowding and filthy conditions in the prison, and stated that:

"We came here to see and hear for ourselves how exactly the jailbreak happened. We have found that prison management handed over the control of the area being renovated to the construction company, and prison security was compromised in the process.

The National Commissioner of Correctional Services, Khulekani Sitole, also visited the prison, but refused to condemn all the officials at the prison. He pointed out that it was not easy to work in overcrowded conditions. The prisoner-to-officer ratio was supposed to be 20 to 1 , but currently stood at 50 to $1^{54}$

The following month, it was reported that the head of the Empangeni Prison in KwaZulu-Natal, Mr Jabulani Zikhali, together with two other officials, were facing suspension following the mass escape of 31 awaitingtrial prisoners. The prisoners had escaped by boring a hole through a corrugated iron roof. A spokesperson for the Department of Correctional Services commented on the dilapidated state of KwaZulu-Natal's prisons as follows: "Some of these prisons are almost 100 years old and are rotten". 55 Two months later, it was reported that 11 of the 31 awaiting-trial prisoners who had escaped from the Empangeni Prison had been recaptured - but that a further 14 prisoners had escaped from that prison in separate incidents. Only three of those 14 escapees had been recaptured. The Minister of Correctional Services, Mr Ben Skosana, announced that four prison officials at the Empangeni Prison were to be suspended and that the management was to be redeployed. ${ }^{56}$ In an amusing twist to this saga, it was reported that the last group of prisoners to escape from the Empangeni prison had left a note stating that they wished to be at home during the Christmas period. In order to help prevent further escapes from the Empangeni and Pietermaritzburg prisons during the Christmas season, it was decided to transfer a number of prominent and dangerous prisoners, held in these prisons, to other prisons. This would also help ease the problem of overcrowding, which was particularly bad in the case of the Empangeni prison which was $210 \%$ overcrowded at this time. ${ }^{57}$

Allegations surfaced that, in certain cases, prisoners who attempted to escape were severely assaulted by warders. For example, it was reported that a prisoner by the name of Peter Sethabela had died from injuries sustained during an attempt to escape from the Vereeniging Prison. Three other prisoners who - together with Sethabela - were facing charges ranging from robbery and theft to murder, succeeded in escaping from custody. Sethabela's family alleged that they had received reports from two prisoners that Sethabela was repeatedly and severely beaten up by warders

\footnotetext{
23 September 1999 Natal Witness 2.

23 September 1999 Natal Witness 2.

23 October 2002 Independent on Saturday 5.

4 December 1999 Beeld 15.

21 December 1999 Beeld 8.
} 
at the prison after he had been caught trying to escape. His sister told the Sowetan that:

"When I went to the Government mortuary to identify and clean his body, he had several injuries. His left eye had been damaged and he had a deep gash at the back of his head. His cheek bones, left leg and a hand were broken. And his neck was twisted."

Certain prisoners, with the help of corrupt prison officials, became true escape artists. For example, during August 2001, a prisoner by the name of Mzimasi Thungulu escaped from the St Albans prison in the Eastern Cape. $\mathrm{He}$ had been sentenced to 60 years' imprisonment for murder, armed robbery and attempted murder. He had conducted a reign of terror in the Border-Transkei area, during which time he was involved in a string of murders, including that of a policeman. ${ }^{59} \mathrm{He}$ was known by the nickname "McGyver", since he had been successful in escaping from custody on no fewer than nine previous occasions. The Correctional Services Commissioner for the Eastern Cape, Raphapheng Mataka, stated that he was sure that Thungulu had been assisted in his escape by a group of prison officials acting as part of a syndicate:

"It was not the first time Thungulu received assistance from our officials - all of his escapes have involved an official or officials ... there is a group of officials who are involved and we know them and we are on their trail."

The Eastern Province Herald quoted a "reliable source" as stating that the prison officers had assisted Thungulu to escape so that they could kill him. The source alleged that the reason the officers wished to murder Thungulu, was because he had confidential information about the illegal activities of these prison warders. It was alleged that the prison officers used Thungulu to sell drugs inside the St Albans Prison. Shortly after the escape of Thungulu, three staff members at the St Albans prison were suspended. In addition, Clifford Mshunqane replaced Silverman Nomzanga as the head of the prison. Thungulu was recaptured shortly afterwards. ${ }^{61}$ Unfortunately, the problem of escapes from prisons in the Eastern Cape was soon to return to haunt prison officials in that region. A mere two months after Thungulu had been recaptured, the Eastern Province Herald reported that nine awaitingtrial prisoners had escaped from the Dordrecht prison. The newspaper stated in an editorial that:

"Eastern Cape jails must be among the easiest in the world to escape from ... $[T]$ he ongoing escapes from our prisons and police cells are shocking testimony of ineptitude and corruption ... Earlier this week nine awaiting-trial prisoners, armed with knives, overpowered policemen and warders and broke out of the Dordrecht prison. How good can the discipline and security be if nine prisoners can get knives in jail ... the disastrous statistics are a symptom of ineffective methods, weak legislation and corrupt officials? The bottom line

\footnotetext{
24 December 1999 Sowetan 4.

28 August 2001 Eastern Province Herald 3.

25 August 2001 Eastern Province Herald 2.

61 Ibid; 28 August 2001 Eastern Province Herald 3.
} 
is that our criminals are in paradise, often aided and abetted by the people into whose captivity they are entrusted.

Certain of the escapes during the period under review involved violence. For example, during September 2001, one prisoner was killed and another seriously wounded during an attempted escape by three prisoners from Waterval Prison in Utrecht. The prisoners had dispossessed a prison guard of a firearm, which he had taken into the prison in contravention of regulations. A gun battle ensued between the escapees and two policemen who observed the incident. Both policemen suffered gunshot wounds and one prisoner managed to escape - but was rearrested shortly afterwards. This was not an isolated incident. During May of the same year two prisoners had escaped from the same prison by taking a prison guard hostage. The prison guard was later found murdered, and the escapees were rearrested after several days on the run. ${ }^{63}$

Certain escape attempts were foiled by the authorities. For example, during September 2001 it was reported that a plan to free nine prisoners convicted of a spate of politically-motivated killings in the Richmond area, had been foiled. At least three of the prisoners had been convicted on 20 counts of murder arising from three massacres, and were serving multiple life sentences. Prison authorities intercepted a letter allegedly written to the nine prisoners by certain of their relatives, indicating that an automatic rifle would be smuggled into the Pietermaritzburg New Prison - which could then be used by the prisoners to effect their escape. It was reported that at least four cars were to have been used to convey the escapees to the Swaziland border, and that prominent political leaders were implicated in the plot. The prisoners were transferred to an ultra-maximum security section of the prison, in order to prevent the planned escape. ${ }^{64}$

Assistance by corrupt warders to escapees seems to have played a role in a number of the escapes which took place during the period under review. For example, during January 2002 seven prisoners escaped from the Ingwavuma Prison, while another seven prisoners escaped from the Eshowe Prison. By 19 January 2002, five of the escapees had been recaptured. Three of the prisoners who had escaped from the Eshowe Prison and who were recaptured, alleged that a prison warder had assisted in their escape. They alleged that they had paid the prison warder R2000 to supply them with an angle grinder, which they then used to cut the bars of their cell. The warder was arrested, charged - and appeared in court. A total of five warders were suspended as a result of the incident. The Correctional Services Commissioner for KwaZulu-Natal, Linda Mti, stated that:

"Our preliminary report on the recent escapes exposed serious deviations from policy and procedures. These manifest themselves in gross negligence, bordering on collaborating with escapees and poor management."

6211 October 2001 Eastern Province Herald 4.

638 September 2001 Natal Witness 3.

6412 September 2001 Natal Witness 4; 13 September 2001 Daily News 4.

6516 January 2002 Natal Witness 3; see also 21 January 2002 Natal Witness 2. 
To sum up, although the number of escapes from South African prisons was in decline during the period under review, those escapes that did take place revealed a disturbing pattern of corruption, violence, and the abuse of human rights.

\section{THE SPECTRE OF CORRUPTION CONTINUES TO HAUNT PUBLIC DISCOURSE}

It is certainly no exaggeration to state that, during the post-apartheid period, South African public discourse, across the board, has been haunted by the spectre of corruption on the part of various Government officials and their private-sector allies. ${ }^{66}$ The South African penal system was certainly not spared from allegations of corruption and criminal activity by officials during the post-apartheid period - including the years reviewed in this article. ${ }^{6}$ Disturbing allegations of criminal and corrupt practices perpetrated by prison staff surfaced on a number of occasions during the period under review. For example, during February 1999, a group of 11 prisoners were allegedly assaulted by warders in East London's Fort Glamorgan Prison, following an incident in which a prisoner stabbed and wounded a prison warder. The prisoners were allegedly assaulted by warders with batons, a pick-axe handle and a knife - and then thrown into solitary confinement. Injuries to the prisoners required hospital treatment and included broken hands, legs, arms, lacerations to the face, deep gashes to the head, stab wounds on the head, and smashed teeth. A provisional court order for the release of the prisoners from solitary confinement was obtained on 7 August 1999 and confirmed during September 1999. David Theron, the magistrate who confirmed the final order, held that the detention of the inmates in single cells for six months was unlawful and stated that the atrocities committed by warders were shocking. It was reported that the prisoners had instituted a civil claim against the warders and the Department of Correctional Services for damages, in the amount of R1.2 million. ${ }^{68}$

During August 1999 it was reported that more than 100 complaints had been made to the South African Prisoners Organization for Human Rights by prisoners, who claimed they were being forced to pay prison warders to

66 While myriad quotations could be used in support of this point, the following words of respected constitutional law scholar, Pierre de Vos, seem apposite: "[W]hy did an obviously brilliant, courageous and seemingly deeply-principled struggle hero like Jackie Selebi become corrupt? Why are we confronted almost every day by news of crooked cops, Home Affairs officials and tenderpreneurs? Why does it sometimes feel as if we are being engulfed in a tidal wave (or is it a Tsunami) of sleaze and corruption in South Africa?" See De Vos "On corruption in South Africa" in his "Constitutionally Speaking" blog, dated 5 July 2010, available at: http://constitutionallyspeaking.co.za/on-corruption-in-south-africa/ (accessed 2015-05-08).

67 For a brief discussion concerning allegations of corruption during the period immediately prior to South Africa's second democratic election, see Peté "The Good, the Bad and the Warehoused": The Politics of Imprisonment During the Run-Up to South Africa's Second Democratic Election 2000 13(1) South African Journal of Criminal Justice: 1-56 - Section 7.4 entitled "Corruption" 23-24.

6819 September 1999 City Press 5. 
escort them when they wished to see visitors, or were required to appear in court. According to a spokesperson for the South African Prisoners Organization for Human Rights, Xoliswa Falati: "The prisoners have to plead with relatives to bring them money because they have to pay to survive in prison" ${ }^{69}$ Another spokesperson for the organization, Phineas Mnambathi, stated that:

"It's common practice. If you need to move for any reason - whether it is to go and watch soccer on TV or you need medical attention from the internal hospital - you have to pay. You pay for decent meals. Prison warders have turned their jobs into private businesses which offer nothing for free. The system is in tatters ... I visit prisons at least once a week. And a lot of things I hear, this total abuse of power, I experienced for myself, so I know they are not stories".

According to The Star, in a report published at the same time as the article referred to above, a female inmate of a Gauteng prison had contacted the newspaper on a public telephone, and complained that corruption in the prison was commonplace. She told the newspaper that prisoners who were favoured by warders were able to smuggle goods into the prison and could sell them for a profit. According to this informant, the situation was even worse for male prisoners:

"My husband is in another prison, and it's much worse for men. They have to buy their mattresses and pay for protection if they don't want to be raped or beaten up".

The Star contacted another prisoner for comment. He was a male prisoner confined at Leeukop Medium C Prison, and he stated that:

"You can get anything you want if you have money. But without it you can do nothing ... You pay for everything here. And how much depends on the person you are dealing with. If, for example, you have a case you want dropped, you can give them money and they will arrange things so that you can organize it. That costs R50 or more, depending on the case ... If you pay R100 they let you out for visitations when you don't qualify ... We had a shop going and in April they came and took everything. We had R11 644,67 in cash and a lot of stock. They said they would bring it back in September when they will charge $10 \%$ profit and give us $5 \%$. But that is not fair because it will become their business, set up with our money."

A Democratic Party spokesperson, Mr Hendrik Schmidt, stated that it was intolerable to learn that prisoners were being forced to pay warders for basic rights such as transport and extra blankets:

"Correctional Services Minister Ben Skosana should intervene immediately and problem prisons should be targeted in a coordinated effort to rid the system of corrupt warders and officials ... If collecting evidence is the main obstacle to bringing these people to book, perhaps Mr Skosana should devise

6923 August 1999 Sowetan 6.

7023 August 1999 Pretoria News 3.

7123 August 1999 The Star.1.

72 Ibid; 23 August 1999 Pretoria News 3. 
an alternative system of gathering evidence, whereby prisoners can freely come forward to report cases without any threat to their safety".

The Commissioner of Correctional Services, Khulekani Sitole, responded to the allegations of corruption within his department, by stating as follows: "Lies, lies ... I am running a sound administration and corruption is under control". ${ }^{74}$ In an editorial, The Star responded to Sitole's comment, by stating that:

"We doubt very much that it [i.e. corruption] is under control. That, of course, doesn't mean that no attempts are being made to stamp out corruption. But the big question is whether the system is so rotten that it negates the chance of rehabilitation? In other words, Sitole needs to tell us what the odds are that men and women will emerge with greater integrity when they leave his jails".

Ironically, Khulekani Sitole himself was to fall victim to allegations of corruption made against him. Two researchers at the Centre for the Study of Violence and Reconciliation, Amanda Dissel and Stephen Ellis, commented on Sitole's case, as follows:

“In 1999 Parliament's public-accounts committee found the Commissioner for Correctional Services, Dr Khulekani Sitole, unsuitable for high office in public service and he was allowed to resign. The committee found that Sitole had wasted and misused State money and given himself generous merit awards of more than R100,000. He had also employed 24 players for his personal amateur soccer club and paid their salaries from the Correctional Services budget ....

In defence of the Department of Correctional Services, a spokesperson pointed out that an anti-corruption unit had been formed within the Department during October 1997, and that it had probed 117 cases of alleged corruption in 1998. Since the unit was formed, 11 officials of the Department had been dismissed and 12 officials suspended. However, it seemed that corruption within the penal system was still rife. A spokesperson for the South African Prisoners Organization for Human Rights, Phineas Mnambathi, claimed that the organization had received 400 to 500 complaints of corruption since October 1997. Mnambathi stated that most prisoners were afraid of reprisals from warders, if they were branded as a "snitch". ${ }^{77}$ The month after these comments were made, it was reported that the assistant director of Rooigrond Prison near Mafikeng, Linda Phasiwe, had been suspended due to allegations that she had allowed prisoners to visit their homes. Another official at the Rooigrond Prison,

\footnotetext{
24 August 1999 The Citizen 6.

24 August 1999 The Star 6.

26 August 1999 The Star 18

76 Dissel \& Ellis "Reform and Stasis: Transformation in South African Prisons". Paper for the Centre for the Study of Violence and Reconciliation, first published in Ambitions réformatrices et inertie du social dans les prisons sud-africaines Critique Internationale (2002) 16.

7724 August 1999 The Star 6.
} 
Reuben Motsumi, was also suspended for assisting a prisoner to visit his parents in Rustenburg. ${ }^{78}$

The stress of working in an overcrowded and sometimes corrupt environment clearly exacted a toll on prison staff during the period under review. For example, in August 2000, two wardens at the Westville Prison in Durban died after one of the wardens had shot his colleague and then turned his gun on himself. This followed the escape of a dangerous prisoner from the same prison a few days earlier. The prisoner, Mr Sipho Masuku, had been sentenced to 30 years' imprisonment for robbery and kidnapping. These incidents prompted a personal investigation by the Minister of Correctional Services, Mr Ben Skosana. 79 The Minister blamed overcrowding in South African prisons for the emotional and psychological stress suffered by prison officials: "Related emotional and psychological stress has become a constant ailment with some prison officials - resulting in ineffectiveness, despair, violent treatment of inmates and, at worst, homicide and suicide" ${ }^{80}$ The following month, the Minister announced that 23 officials had been dismissed during the first six months of 2000, following departmental investigations into escapes, fraud, theft and other offences. ${ }^{81}$

As disturbing as they were, the reports of violence and corruption in South African prisons which appeared during the period under review were soon to be overshadowed by shocking accounts emerging from evidence presented to the Jali Commission of Enquiry into allegations of corruption in the Correctional Services Department. This national commission of enquiry was set up in September 2001, following the murder of Thutu Bhengu, the Deputy Correctional Services Commissioner for KwaZulu-Natal. ${ }^{82}$ Bhengu was gunned down in the study of her home near Pietermaritzburg's Napierville Prison, while in the process of finalizing a report on an internal departmental investigation into allegations of wide-scale bribery and corruption within the Department of Correctional Services in KwaZulu-Natal. Following the murder, the Minister of Correctional Services, Ben Skosana, cancelled the internal departmental investigation in favour of a broader national inquiry. During August 2001, Durban High Court Judge, Thabani Jali, was appointed to head this enquiry. ${ }^{83}$ What emerged from this inquiry falls outside the scope of the present article. From the above it is clear, however, that corruption and criminal activity on the part of South African prison officials, constituted a significant theme within public penal discourse in South Africa during the period under review.

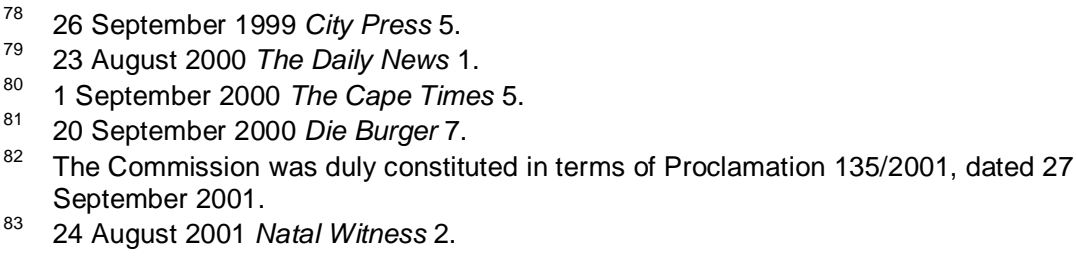




\section{A CONTINUED REIGN OF TERROR BY PRISON GANGS}

A common theme over many years within South African penal discourse, concerns the activities of the notorious "numbers" gangs within South African prisons. ${ }^{84}$ During the period under review, these gangs continued to conduct a reign of terror within the South African penal system. During June 2000, Cape High Court Judge, Dennis Davis, stated that, unless the problem of prison gangs was solved, prisons would continue to produce sufficient criminals to keep crime at a high level. He made these remarks while giving judgment in the case of two prisoners who were convicted of murdering another inmate in the back of a prison truck. ${ }^{85}$ The Minister of Correctional Services stated in Parliament that, in addition to other measures, it was the policy of his Department to separate gang leaders from their gangs:

"The introduction of the C-Max unit and the new super maximum prison where gang leaders and members who participate in violent actions can be separated from the rest of the prison population is a further measure in the fight against gangs".

During the period under review in this article, South African gangs were responsible for acts of almost unbelievable savagery. For example, in September 2000 it was reported that lawyers were preparing to sue the police and the Department of Correctional Services for damages following an indecent assault by gang members on Charles Philander - an awaitingtrial prisoner in Cape Town's Pollsmoor prison. It was alleged that the assault was so brutal that Philander was likely to be incontinent for life. The assault allegedly began in a prison truck, which was returning to Pollsmoor from the Cape Town Magistrate's Court. Gang members allegedly requested Philander to help them to smuggle a dagga parcel into the prison. When he refused, they forced the parcel into his rectum. On their return to the prison, Philander was unable to get help from the warders, and was locked in a cell along with 50 other prisoners. He was then overpowered by gang members, who wanted to retrieve the dagga parcel. He was allegedly jumped on and punched in the stomach in an effort to dislodge the parcel. According to Philander, the gang members then tried to give him an enema with a bottle of water, and eventually retrieved the parcel using a bent wire coat hanger and a white toothbrush. Philander claimed that he was assaulted throughout the night but that his constant screams of pain were ignored. The next

84 See, for eg, Peté "Angels and Demons, Innocents and Penitents: An Analysis of Different 'Characters' Within the Penal Discourse of Apartheid South Africa 1980 to 1984 - Part 1" 2015 48(1) De Jure 55-74 - see Section 3 entitled "Demons and Gangsters - The Explosion of Interest in Prison Gangs"; Peté "The Politics of Imprisonment in the Aftermath of South Africa's First Democratic Election" 1998 11(1) South African Journal of Criminal Justice: 51-83 - see Section 5.2 entitled "Abuse of Human Rights by Prison Gangs" 80-81; Peté "The Good, the Bad and the Warehoused": The Politics of Imprisonment During the Run-Up to South Africa's Second Democratic Election 2000 13(1) South African Journal of Criminal Justice 1-56 - see Section 10 entitled "Prison Gangs: A Continuing Reign of Terror" 39-41.

8526 June 2000 Cape Argus 4.

86 Ibid. 
morning he was transported to hospital, where it was discovered that the extent of his injuries was so severe that he would require reconstructive surgery. According to the Cape Argus, the dagga was eventually recovered from his abdominal cavity. ${ }^{87}$

Another example of the brutality of prison gangs during the period under review, concerns two extremely violent murders which took place at St Albans prison on 31 October 2000. Six prisoners were put on trial for these murders in February 2002. The victims, Andre Lambert and Gavin Frolick, had been stabbed to death with fragments of a broken toilet bowl. All the prisoners involved, including the deceased, allegedly belonged to either the $26 \mathrm{~s}$ or $28 \mathrm{~s}$ prison gangs. ${ }^{88} \mathrm{~A}$ witness in the murder trial - prisoner Mbulelo Noge - gave evidence on how Andre Lambert was killed. According to Noge, one of the accused held Lambert's arms behind his back, while another accused ripped open Lambert's stomach from the chest downwards with a shard of porcelain taken from a broken toilet bowl. Lambert's intestines were then pulled out of the wound. ${ }^{89}$

Fighting between prison gangs was the cause of much of the violence in South African prisons during the period under review. For example, during December 2000, it was reported that a fight involving 52 inmates from opposing gangs had erupted at Leeukop Prison. Members of the 26 and Air Force gangs allegedly attacked one another with sharpened objects and other improvised weapons - resulting in six inmates and a warder being injured. ${ }^{90}$ During November the following year, a violent conflict broke out in the St Albans Prison between members of the 28s and 26s prison gangs, as well as prisoners not affiliated to any of the gangs. At least 35 prisoners were injured and a juvenile inmate was killed. ${ }^{9}$ The Minister of Correctional Services, Mr Ben Skosana, visited the St Albans prison to take personal stock of the situation, and expressed his regret at the incident. ${ }^{92}$ Yet another incident of gang violence was reported in March 2002 - this time in the Brandvlei Prison, Worcester. A suspected gang member and a warder were seriously injured. ${ }^{93}$

Despite the continuing gang violence outlined above, there had been positive developments in certain South African prisons by the time of South Africa's second democratic election. For example, in his excellent book The Number, Jonny Steinberg reviews developments at Cape Town's notorious Pollsmoor Prison between 1995 and 2000. During the early years of South Africa's democracy - January 1995 to December 1997 - Steinberg notes that there were 336 recorded assaults by warders on inmates, and over 400 recorded assaults on inmates by inmates, making the Pollsmoor Admission

\footnotetext{
19 September 2000 Cape Argus 8.

26 February 2002 The Herald 4.

1 March 2002 The Herald 4.

17 December 2000 Sunday World 6.

21 November 2001 The Herald 3.

24 November 2001 The Herald 6.

4 March 2002 Cape Argus 2.
} 
Centre "probably the most violent place in Cape Town." ${ }^{94}$ This virtual state of war was brought to an end following reforms introduced into the prison by a certain Jonny Jansen, who assumed control of the prison during 1997. According to Steinberg, when Jansen took control of the prison:

"The gangs controlled Pollsmoor's corridors openly and brazenly. His own staff were armed to the teeth and patrolled the prison with their hands clenched round their batons."

Following Jansen's reforms, however, the situation improved significantly. Steinberg comments as follows:

"In 1999 there were 11 recorded assaults on inmates by inmates, down from 78 in 1995. Recorded assaults by warders on inmates were down to three. The prison truly was a different place. An outsider who visited the prison regularly between 1997 and 2000 told me: 'It was extraordinary to see the prison change before my eyes. In 1997, you walked through the corridors with armed guards. The tension was so severe you felt the goose bumps rise on your skin. By 1999, you walked freely through the prison, talking to inmates casually. The food was the same, the overcrowding was the same, but the atmosphere was that of a different planet."'

Despite the positive developments referred to above, it is probably still fair to state that, during the period under review, the South African penal system was unable to free itself from the fear and violence engendered by prison gangs. The gangs continued to conduct a reign of terror within the prisons which impacted negatively on the basic human rights of ordinary prisoners. The problem continued to be highlighted within public discourse, as it had been for many decades - but the numbers gangs continued to operate as an entrenched part of the South African penal system.

\section{$7 \quad$ CONCLUSION}

South Africa's second democratic election held on 2 June 1999 may be said to have marked the end of the "honeymoon period" which followed the country's transition to democracy in 1994. The mood of many South Africans became more pessimistic as they were forced to reconcile themselves to the fact that the end of apartheid did not mean a quick end to deeply entrenched social and economic problems. South Africans were united in their fear and revulsion at what was perceived to be unacceptably high levels of crime in the country. This generally negative mood filtered into the public discourse surrounding imprisonment at this time. What emerges from a close examination of this discourse - gleaned from a large number of reports in a wide range of national and local newspapers, as well as from official sources - does not paint a pretty picture. The period was characterized by the

94 Steinberg The Number: One Man's Search for Identity in the Cape Underworld and Prison Gangs Johannesburg: Jonathan Ball (2004) 311.

95 Steinberg The Number: One Man's Search for Identity in the Cape Underworld and Prison Gangs Johannesburg: Jonathan Ball (2004) 321.

96 Steinberg The Number: One Man's Search for Identity in the Cape Underworld and Prison Gangs Johannesburg: Jonathan Ball (2004) 332. 
continued abuse of the basic human rights of many of those unfortunate enough to find themselves behind bars in South African prisons at this time. As during the pre-election period, chronic overcrowding within the prisons continued to be the main problem confronting prison authorities. This intractable problem exacerbated a host of evils which beset prisoners in South Africa during the post-election period. Living conditions within many South African prisons were appalling; prison gangs continued to conduct a reign of terror; the HIV/AIDS epidemic within South African prisons escalated alarmingly; the conditions of detention of children were highly unsatisfactory; and corruption among prison staff continued to impact negatively on the entire penal system. Sadly, for many prisoners in South Africa, the second democratic election did not lead to an improvement in their conditions of detention - but rather to the continued violation of their human rights. Moreover, anyone in South Africa who took the time to read any of the national or local newspapers must have been aware of this fact. If there is any truth to Fyodor Dostoevsky's famous maxim quoted at the beginning of Part One of this article, it seems clear that South African society must be judged harshly for the generally poor treatment of its prisoners during the years following the country's second democratic election.

7 "The degree of civilization in a society can be judged by entering its prisons". From Fyodor Dostoevsky (1862) The House of the Dead translated by Constance Garnett and quoted in Shapiro, FR (2006) The Yale Book of Quotations New Haven: Yale University Press, as reflected in the 2013 IOS Application created and developed by English Channel Inc Tokyo. (accessed 2015-04-16). 